\title{
A Simulation Model for Road and Maritime Environmental Performance Assessment
}

\author{
J. J. Usabiaga ${ }^{1}$, M. Castells ${ }^{1}$, F. X. Martínez, A. Olcer $^{2}$ \\ ${ }^{1}$ Department of Nautical Sciences and Engineering, Universitat Politècnica de Catalunya, Barcelona, Spain; ${ }^{2}$ World Maritime Uni- \\ versity, International Maritime Organization, Malmö, Sweden. \\ Email: mcastells@cen.upc.edu, aio@wmu.se
}

Received March 18 ${ }^{\text {th }}, 2013$; revised April 20 ${ }^{\text {th }}, 2013$; accepted May $19^{\text {th }}, 2013$

Copyright (C) 2013 Juan José Usabiaga Santamaría et al. This is an open access article distributed under the Creative Commons Attribution License, which permits unrestricted use, distribution, and reproduction in any medium, provided the original work is properly cited.

\begin{abstract}
The White Paper published in 2011, Roadmap to a Single European Transport Area [1], urges on a 30\% modal shift of road freight over $300 \mathrm{~km}$ to other modes (rail, maritime and inland waterways) by 2030, and more than 50\% by 2050 . However the environmentally friendly performance of maritime transport regarding air pollutant emissions in comparison with road transport is in doubt. This paper presents a three dimension simulation model, in which performed transport work, arisen emissions and produced impact are estimated and inter-related for the assessment of the environmental performance of both road and maritime transport. The simulation model will be a valuable decision making tool for policymakers as it enables the precise assessment of considered transport alternatives in the EU27 until 2020, and hence supports the design of future intervening actions.
\end{abstract}

Keywords: Transport; Emissions; Environmental Performance; Policy Assessment

\section{Introduction}

Maritime transport is, after road transport, the most importent mode of transportation within the European transport system, being responsible for $36.8 \%$ of the intra-European transport in 2009 [2].

In the last decades, based on a presumed environmentally friendly performance, intra-European maritime services, also known as Short Sea Shipping (SSS) services, have been favored by numerous supporting actions coming from both national governments and the European Union (EU): Marco Polo and Trans European Network of Transport (TEN-T) programs, the most relevant. However when comparing SSS with rail and road transport, its main competitors; several doubts arise with regards to its greener performance. Substantial $\mathrm{CO}_{2}$ emissions originate in transport sector $(25 \%$ in 2007 for the EU15, excluding the international traffic departing from the EU) and almost all of this comes from road transportation (93\% in 2007 for the EU15) [3]. There is no doubt about maritime transport being the most energy efficient transport mode and therefore it is on average the transport alternative with lower $\mathrm{CO}_{2}$ emissions per transport work unit [4]. But that does not mean it is the greenest alternative in terms of air pollutants $\left(\mathrm{NO}_{\mathrm{x}}, \mathrm{VOCs}, \mathrm{PM}_{2.5}\right.$, $\mathrm{SO}_{2}$,) emissions, which are not solely dependent on fuel quality. Aspects such as engine technologies, types of fuel, emissions abatement technologies, emission standards, logistical factors and sensitivity of concerned areas make all the difference in favor or against each mean of transportation. In fact there are studies that have shown that maritime traffic emissions can affect $\mathrm{NO}_{2}$, $\mathrm{PM}_{10}$ and $\mathrm{SO}_{2}$, concentration in coastal areas [5]. On the other hand, an optimized infrastructure investment model is developed to evaluate local air pollution of maritime transport and its effects as a result of manoeuvring, hoteling, and load/unload activities at ports [6].

This paper's objective is to bring some light to SSS's environmental performance assessment in comparison with that of road transport and to lay foundations for future intervening actions. Therefore a computer model is built up characterizing the two transport chains under investigation. The model considers both local and rural externalities from direct emissions of air pollutants $\left(\mathrm{NO}_{\mathrm{x}}\right.$, VOCs, $\mathrm{PM}_{2.5}, \mathrm{SO}_{2}, \mathrm{NH}_{3}$ ) and the global impact of $\mathrm{CO}_{2}$ emissions. Only road transport and SSS are considered, as currently rail transport is not an actual alternative Europe-wise due to interoperability issues between 
countries.

There are a few reports [7-13], but not generalized simulation models, comparing SSS's environmental performance in comparison with other means of transport. The developed model shows several strengths and opportunities when comparing it with the aforementioned reports. In the following paragraphs these are highlighted.

A distinctive particular of the model is that the environmental performance is measured using the externalities produced by air pollutant and greenhouse gas (GHG) emissions, instead of by the amount of produced emissions. This is a significant issue as emission impacts depend on the sensitivity of the emission site and therefore same amounts of emissions do not necessarily present same impacts. In this respect, the model is designed following a bottom up approach enabling spatially disaggregated emission inventories, which in the end allow geographically characterized impact valuations.

Following the introduction section (Section 1), this paper continues with the methodology (Section 2) where the relationships and calculations underlying the computer model are described. Once the methodology is known, a case study is presented (Section 3) showing the capabilities of the model. Afterwards results are discussed (Section 4) in order to finally present some conclusions and further recommendations (Section 5).

\section{Methodology}

The simulation model is broke down into four major sections shown in Figure 1. The first and second sections deal with transport activity and fleet characterization parameters respectively, i.e. emission and cost drivers.

The third section leads us to an emission index for each of the transport alternatives and scenarios selected. Finally the fourth section uses main cost drivers introduced in the first two sections of the model, to determine the intensity (sensitiveness) of damages arising from transport activities and permitting the assessment of the environmental performance of the considered transport.

\subsection{System Boundaries and Main Assumptions}

The developed model is able to simulate the environmental performance of road and SSS alternatives taking into account air pollutants and $\mathrm{CO}_{2}$ emissions. In order to understand its working capacity, the extents of the simulated transport chains are represented within a dashed green rectangle in Figure 2.

For road transport both loaded and empty legs are considered as usually trucks do not reload the trailer at the initial destination point. In the case of SSS combined transport chains, besides the maritime leg, pre and post haulage legs are taken into account as the origin and des-

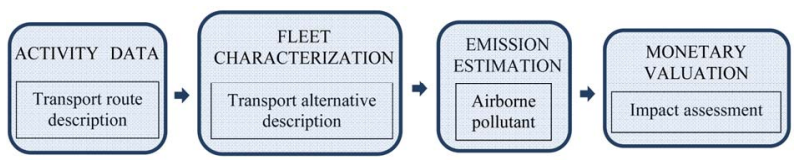

Figure 1. Generalized model breakdown. Source: Own.
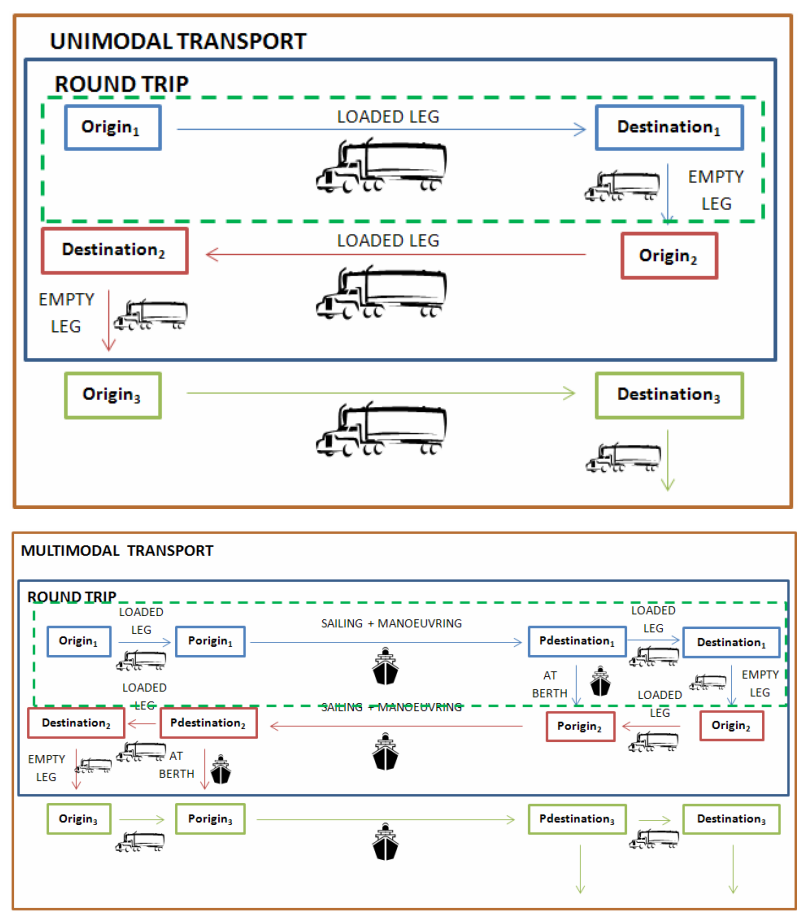

Figure 2. Road and SSS transport chains system boundaries Source: Own.

tination of the cargo that will rarely be placed at seaports. Moreover the empty leg after unloading is also considered.

The models only consider direct emissions during the actual transport, indirect emissions taking place upstream or downstream are not considered due to lack of reliable data. When it comes to air pollutants emissions estimation, the model considers emissions of $\mathrm{NO}_{\mathrm{x}}$, VOCs, $\mathrm{PM}_{2.5}$ and $\mathrm{SO}_{2}$ for both transport alternatives. $\mathrm{NH}_{3}$ emissions are also considered for road transport though. Regarding GHG emissions, only $\mathrm{CO}_{2}$ emissions are considered. Point out that only emission factors for conventional fossil fuels have been considered (diesel fuel, heavy fuel oil, marine diesel oil and marine gas oil).

The following factors, represented in Figure 3, are considered to influence the environmental performance of transport chains $(€ / \mathrm{km})$ and therefore considered in the model:

- Logistical factors.

o Pre and post haulage legs.

o Detouring, covered distance difference between transport alternatives.

o Vehicle capacity.

o Vehicle utilization. 

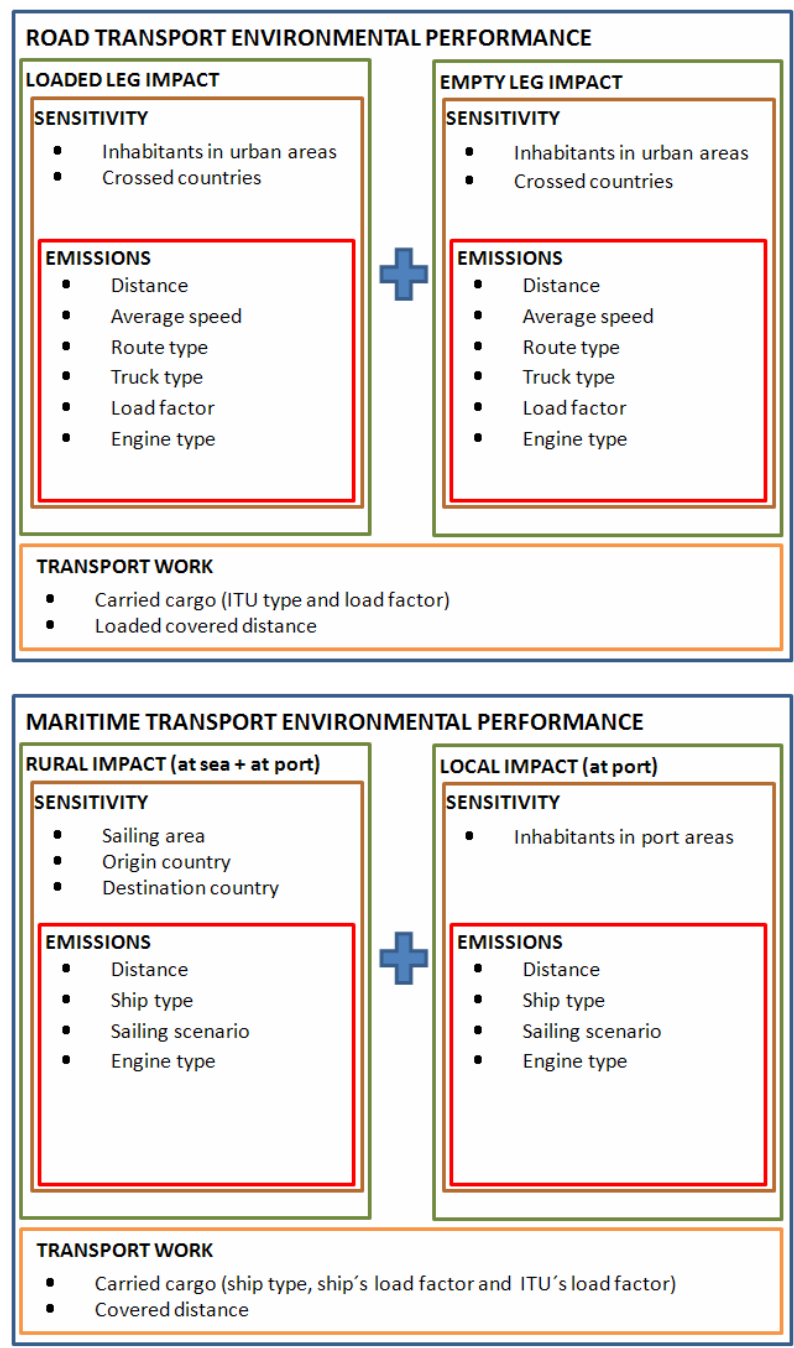

Figure 3. Road transport and SSS transport chains emissions and costs drivers. Source: Own.

- Emission standards.

- Emission abatement or engine technologies.

- Energy efficiency.

- Sensitiveness of the emission site.

When it comes to the vehicles being used in road and SSS alternatives, the following assumptions have been made:

- For road transport, configurations formed by a road tractor coupled to a semitrailer or car carrier with a maximum permissible weight between 40 to 50 tons.

- In the case of SSS only the ship types (RoRo, RoPax, ConRo, Car Carrier and Container ship) competing for cargo carried by road and their corresponding loading units (semi-trailer, car carrier, Twenty-foot Equivalent Unit (TEU), Forty-foot Equivalent Unit (FEU) and Container Equivalent Unit (CEU)) are considered.

The model's geographical scope is limited to the EU27 and its surrounding seas (Mediterranean, Atlantic, Eng- lish Channel, North Sea and Baltic Sea) due to data availability.

\subsection{Road Transport Model}

The road transport model has been designed bearing in mind simplicity, input data availability and accuracy; trying to represent comprehensively all singular characteristics leading to the production of actual emissions and impacts of this mean of transportation. This model uses a top-down approach for fleet characterization purposes and a bottom-up approach for geographical characterization of emissions. In this manner, the model achieves a comprehensive assessment, taking into account the characteristics of the emitting truck type and the specifics of each emission place. Figures $\mathbf{4}$ and $\mathbf{5}$ describe in brief the road transport model. These figures show emission and cost drivers together with their interrelations.

\subsubsection{Activity Data}

In this section parameters describing the considered road transport link (urban, rural and highway segments) are the inputs. These parameters are some of the necessary data to be able to calculate emissions and their impact in sections three and four respectively.

\subsubsection{Fleet Characterization}

Under this section the European truck fleet engaged in international freight services and competing with SSS services is characterized. The truck class, payload capacity and the fleet's engine technology (Euro I $-\mathrm{V}$ ) are reviewed.

\subsubsection{Emission Estimation}

The methodology quoted as Tier 3 for exhaust emissions calculation from road transport in the EMEP/EEA air pollutant emission inventory guidebook 2009, part B, chapter 1.A.3.b., is used [14]. This methodology requires detailed truck movement data besides technical information on trucks being considered.

Once all the relevant data for the model has been introduced, this will give emission results for each of the considered road transport stages, air pollutants and GHGs. Emissions of $\mathrm{NO}_{\mathrm{x}}, \mathrm{VOCs}, \mathrm{PM}_{2.5}, \mathrm{SO}_{2}, \mathrm{NH}_{3}$ and $\mathrm{CO}_{2}$ are calculated.

$\mathrm{SO}_{2}$ and $\mathrm{CO}_{2}$ emissions are proportional to the fuel consumption and the sulphur and carbon content in the fuel respectively; however emissions of the rest pollutants are calculated according to empirical formulas presented on the EMEP/EEA study for the considered truck class and capacity.

\subsubsection{Impact Valuation}

Two types of impacts are distinguished for airborne pollutants emissions: a site specific local impact and a coun- 


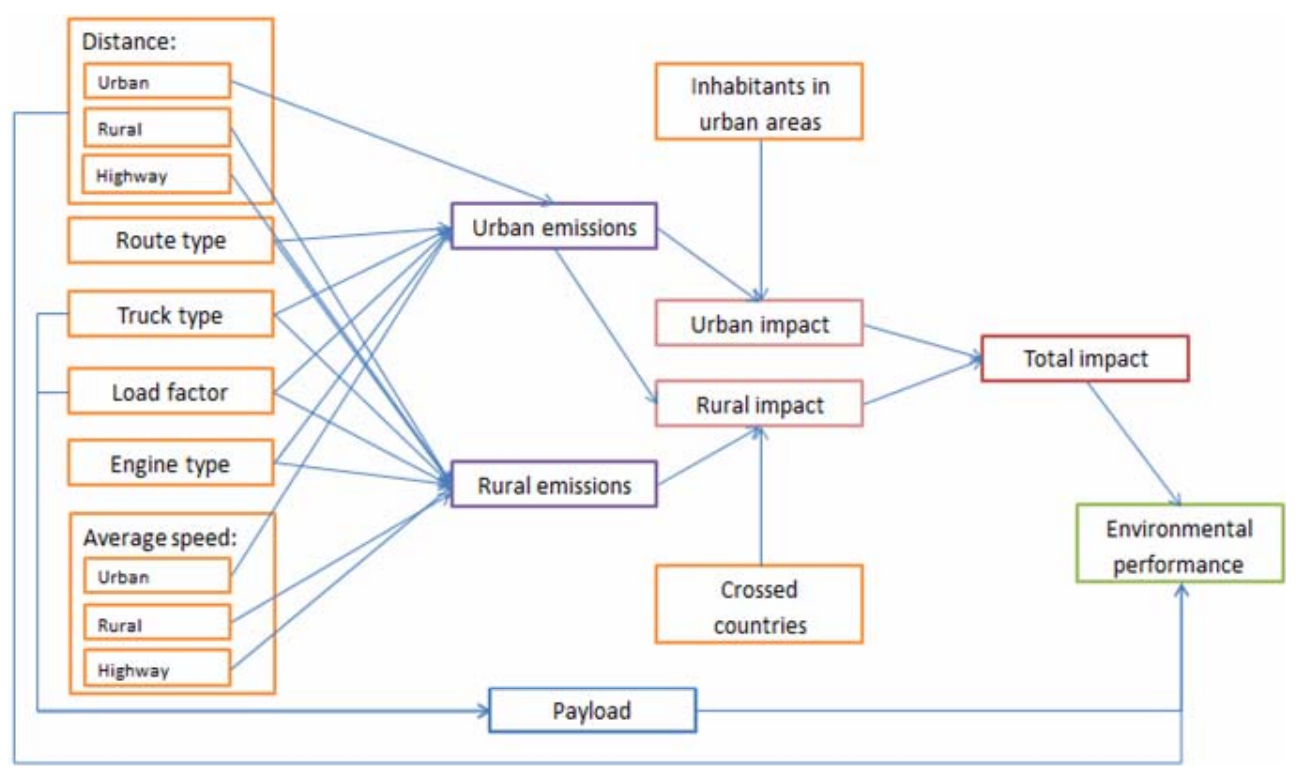

Figure 4. Road transport's environmental performance model. Source: Own.

\begin{tabular}{|c|c|c|c|c|c|c|c|c|}
\hline \multicolumn{3}{|l|}{ Urban } & \multicolumn{3}{|l|}{ Rural } & \multicolumn{3}{|c|}{ Highway } \\
\hline \multirow{5}{*}{$\begin{array}{l}\text { Route type (Gradient): } \\
\text { Load factor: } \\
\text { Engine type: } \\
\text { Average Speed }(\mathrm{km} / \mathrm{h}) \text { : } \\
\text { Length }(\mathrm{km}) \text { : }\end{array}$} & \multicolumn{2}{|c|}{ Flat } & Route type (Gradient): & \multicolumn{2}{|c|}{ Flat } & Route type (Gradient): & \multicolumn{2}{|c|}{ Flat } \\
\hline & \multicolumn{2}{|c|}{$100 \%$} & Load factor: & \multicolumn{2}{|c|}{$100 \%$} & Load factor: & \multicolumn{2}{|c|}{$100 \%$} \\
\hline & \multicolumn{2}{|c|}{ Fleet average } & Engine type: & \multicolumn{2}{|c|}{ Fleet average } & Engine type: & \multicolumn{2}{|c|}{ Fleet average } \\
\hline & \multicolumn{2}{|c|}{40} & Average Speed: & \multicolumn{2}{|c|}{60} & Average Speed: & \multicolumn{2}{|c|}{80} \\
\hline & \multicolumn{2}{|c|}{50} & Length: & \multicolumn{2}{|c|}{250} & Length: & \multicolumn{2}{|c|}{750} \\
\hline \multirow{7}{*}{$\begin{array}{l}\text { Average inhabitants in the urban area: } \\
\text { Country1: } \\
\text { Country2: } \\
\text { Country3: } \\
\text { Country4: }\end{array}$} & \multicolumn{2}{|c|}{1000000} & \multirow{7}{*}{$\begin{array}{l}\text { Country1: } \\
\text { Country2: } \\
\text { Country3: } \\
\text { Country4: } \\
\text { Country5: } \\
\text { Country6: } \\
\text { Country7: }\end{array}$} & France & $50 \%$ & \multirow{7}{*}{$\begin{array}{l}\text { Country1: } \\
\text { Country2: } \\
\text { Country3: } \\
\text { Country4: } \\
\text { Country5: } \\
\text { Country6: } \\
\text { Country7: }\end{array}$} & Spain & $20 \%$ \\
\hline & Spain & $50 \%$ & & Italy & $50 \%$ & & France & $40 \%$ \\
\hline & Italy & $50 \%$ & & NA & $0 \%$ & & Italy & $40 \%$ \\
\hline & NA & $0 \%$ & & NA & $0 \%$ & & NA & $0 \%$ \\
\hline & NA & $0 \%$ & & NA & $0 \%$ & & NA & $0 \%$ \\
\hline & & & & NA & $0 \%$ & & NA & $0 \%$ \\
\hline & & & & NA & $0 \%$ & & NA & $0 \%$ \\
\hline
\end{tabular}

Figure 5. Truck activity and fleet characterization data input sheet. Source: Own.

try specific rural impact. Both local and rural impacts are quantified. However the local impact is only present at urban stages.

The urban impact is produced at a local scale and just after the pollutants, $\mathrm{PM}$ and $\mathrm{SO}_{\mathrm{x}}$ primarily, have been released. Local impact estimations need of great emission site detail; therefore, a bottom-up approach has been chosen for the emissions' geographical characterization [15]. On the other hand the rural impact is country specific, and therefore its quantification does not require that much and precise information.

For local impact quantification purposes the methodology provided in "Benefits Table Database: Estimates of the Marginal External Costs of Air Pollution in Europe (BETA)" study is used [16].

In other respects and regarding rural impact quantification the Clean Air For Europe project (CAFE) [17] is used. This project provides the model with emission costs for the considered airborne pollutants and the EU27 countries excluding Cyprus.

\subsection{SSS Combined Transport Model}

This model is composed by two road legs, pre and post haulage legs, and one main maritime leg, the SSS leg. The model used for the pre and post haulage legs is the previously introduced road transport model, but for the maritime leg a specific simulation model has been designed, Figure 6. On balance the combined transport model is just a composition of two unimodal models, one reproducing road transport and another one reproducing maritime transport.

\subsubsection{Activity Data}

In this section parameters describing the route being considered as well as the ship type being used need to be selected by the model user in order to perform consequent calculations with regards to the environmental performance of maritime transport. It is important to define all the emission and cost drivers to achieve a realistic emissions and impact estimation. The selected SSS alternative, that is the ship type, the sailing scenario and 


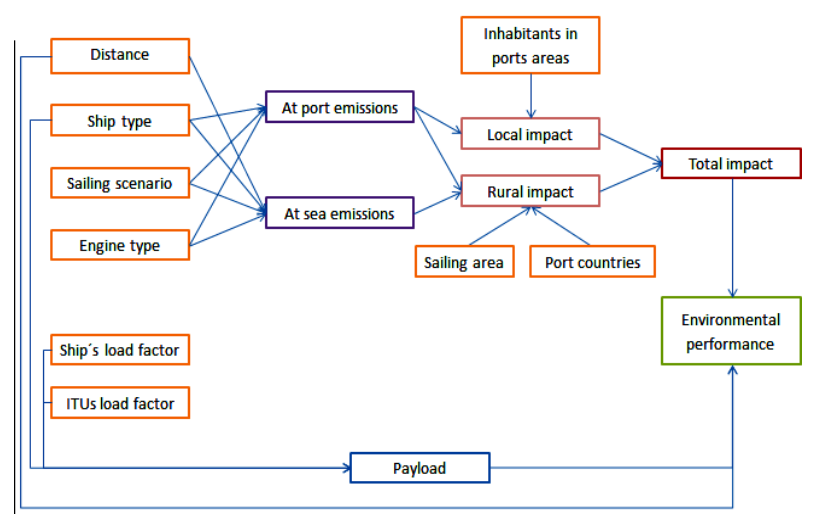

Figure 6. Environmental performance model of maritime transport. Source: Own.

the sailing distance will determine the amount of emissions, whereas the sailing area and the origin and destination ports will determine the sensitivity of affected areas, and hence the impact. Finally logistical factors will allow representing the caused impact in transport work units and therefore enable the comparison of performances between different transport chains.

\subsubsection{Fleet Characterization}

In the maritime alternative the fleet characterization is very important, depending on the considered ship type emission factors differ significantly. A bottom up approach was conducted to provide the research with the consistency given by the consideration of different and detailed input variables. For this purpose, the Lineport database made available by the Valenciaport Foundation and which records all ships engaged in SSS services competitive with road transport was used. Five different ship types were found within the maritime fleet competing with road transport: container ships, car carriers, RoRo ships, RoPax ships and ConRo ships. Once all these ships were identified, using the Fairplay Seaweb database all relevant factors that give rise to ship airborne emissions were found. Except auxiliary engine characteristics (number, type and power), for which assumptions done by Entec 2010 [18] were followed: medium speed diesel (MSD) and high speed diesel (HSD) engines evenly distributed and fix AE/ME power ratios per vessel type. For fleet characterization purposes a database formed by 11 ships engaged in SSS services and calling at Spanish ports during years 2010 and 2011 was used. A total of 400 ships composed the mentioned database.

\subsubsection{Emission Estimation}

The methodology quoted as Tier 3 for airborne emissions calculation from international navigation, national navigation, national fishing and military (shipping) in the EMEP/EEA air pollutant emission inventory guidebook 2009, part B, chapter 1.A.3.d is used [19]. This method- ology requires detailed ship movement data besides technical information on ships being considered. Further focusing on the emissions estimation methodology demonstrates that this work follows the method using data on installed main and auxiliary engine power, engine load factors and total time spent on each navigation phase. The Tier 3 method also employs specific emissions factors depending on the engine type, fuel type and navigational phase.

Four air pollutants and one GHG emissions are estimated for maritime transport: $\mathrm{NO}_{\mathrm{x}}, \mathrm{VOCs}, \mathrm{PM}_{2.5}, \mathrm{SO}_{2}$ and $\mathrm{CO}_{2}$. Emissions of the two latter compounds are proportional to the fuel consumption as well as to the sulphur or carbon content in the fuel respectively. However the estimation of emissions of the rest of pollutants is not straightforward as varies with fuel type, sulphur content and engine operation mode (maneuvering, at berth or at sea). The emission factors update is made following the methodology and assumptions described in UK Ship emissions inventory and in the Transphorm Deliverable D1.2.3 [20], deriving from IVL and Lloyd's emissions datasets.

\subsubsection{Impact Valuation}

Once emissions for each of the navigation phases are known, the impact of these must be quantified. As for road transport, two types of impacts are distinguished from emissions to air: a site, seaport, specific local impact and a country or sea specific rural impact. Both local and rural impacts are quantified for maneuvering and at berth phases. However in the sailing phase only a rural impact is present.

As for the road model, the impact quantification is achieved following BETA and CAFE projects. The BETA project is relevant for local impact quantification and for joining both rural and local impacts during maneuvering and at berth stages. On the other hand, the CAFE project is relevant as it provides costs per emitted pollutant for each of the EU27 countries and sailing areas. As Cyprus, the English Channel is not within the dataset of the CAFE programme and therefore based on the surrounding countries emission costs are estimated.

\subsection{Scenario Analysis}

Once the general environmental performance assessment model was developed, scenarios for the comparison of transport alternatives were built up. The scenarios were not randomly created; the current and future regulatory frameworks regarding emissions were revised, with the objective of identifying key dates and areas in which the regulatory framework would change and hence alter transport alternatives' environmental performances. Besides the change on emission factors due to the enforcement of new emission standards, it is also needed to pro- 
ject forward the fleets recycling process to be able to forecast the introduction of new engine technologies into both road and SSS fleets. For this purpose life cycles of 11 years for trucks and of 25 years for ships are considered. Moreover the fleet is assumed to be evenly distributed along its life cycle what results in an annual replacement rate of $9.1 \%$ for the truck fleet and $4 \%$ for the SSS fleet on the basis that overall fleets remain constant. These scenarios will enable the model to conduct comparative environmental performance analyses not only for current scenarios, but for future scenarios; providing the model with forecasting and in advance policy measure testing abilities.

\subsubsection{Road and Maritime Regulatory Frameworks}

In the last two decades, starting in the 1993 with the first Euro I standard, road transport has improved significantly its environmental performance regarding emissions to air (CO, $\mathrm{NO}_{\mathrm{x}}, \mathrm{HC}$ and $\left.\mathrm{PM}\right)$, Figure 7. A set of emission standards known as the Euro standards have been progressively introduced since 1993 . The next and more stringent standard, so called Euro VI, will be implemented by the end of 2013 reducing even more road transport's emissions to air. Moreover road transport has also improved in sulphur emissions to air by limiting the sulphur content on diesel fuels (Directive 2009/30/EC [21] and Directive 98/70/EC [22]). Currently and since 2009 the limit is in $10 \mathrm{ppm}$ which is considered to be effectively "zero" content. With regards to $\mathrm{CO}_{2}$ emissions road has not achieve significant improvements as this GHG emission is proportional to the fuel consumption and the carbon content in the fuel and neither of these have been significantly reduced (Table 1).

Unlike road transport, maritime transport has not been regulated with regards to emissions to the air until recently. Was the MARPOL 1973/1978 convention which through its Protocol of 1997 including the Annex VI introduced for the first time standards to prevent the air pollution from ships in May 2005. In this first version of the Annex VI a global sulphur cap limiting the sulphur content in the fuel to $4.5 \%$ was introduced. $\mathrm{NO}_{\mathrm{x}}$ emissions resulted also limited through the adoption of the $\mathrm{NO}_{\mathrm{x}}$ Technical Code (Tier I and Tier II standards), Figure 8, and a more stringent $\mathrm{SO}_{\mathrm{x}}$ emission control area (ECA) was established in the Baltic Sea where the sulphur content in the fuel was limited to 1.5\%. In July 2005 the MARPOL Annex VI resulted amended and new North Sea and English Channel $\mathrm{SO}_{\mathrm{x}}$ ECAs were introduced, although these were not fully enforced until November 2007. The last review of the MARPOL Annex VI [23] took place in 2008 when a progressive reduction of SOx emissions from ships was planned and introduced to the annex: reducing the global sulphur cap to $3.5 \%$ by January 2012 and to $0.5 \%$ by 2020 subject to a previous
Table 1. Evolution of emission standards for heavy duty vehicles (HDV). Source: Own, based in directives 88/77/EC, 1999/96/EC, 2005/55/EC, 2005/78/EC and 2007/46/EC.

\begin{tabular}{ccccc}
\hline \multirow{2}{*}{ Euro Standard } & \multicolumn{4}{c}{ Emissions to air } \\
\cline { 2 - 5 } & $\begin{array}{c}\mathbf{C O} \\
\mathbf{( g / k W h})\end{array}$ & $\begin{array}{c}\mathbf{H C} \\
\mathbf{( g / k W h})\end{array}$ & $\begin{array}{c}\mathbf{N O}_{\mathbf{x}} \\
\mathbf{( g / k W h})\end{array}$ & $\begin{array}{c}\mathbf{P M} \\
\mathbf{( g / k W h})\end{array}$ \\
\hline Euro I (October 1993) & 4.9 & 1.23 & 9 & 0.4 \\
Euro II (October 1996) & 4 & 1.1 & 7 & 0.15 \\
Euro III (October 2001) & 5.45 & 0.78 & 5 & 0.16 \\
Euro IV (October 2006) & 4 & 0.55 & 3.5 & 0.02 \\
Euro V (October 2009) & 4 & 0.55 & 2 & 0.02 \\
Euro VI (October 2013) & 4 & 0.16 & 0.4 & 0.01 \\
\hline
\end{tabular}

Note: Euro I and II emissions standards are not directly comparable with those for Euro III or the later because of changes to the duty cycle used for each of these standards.

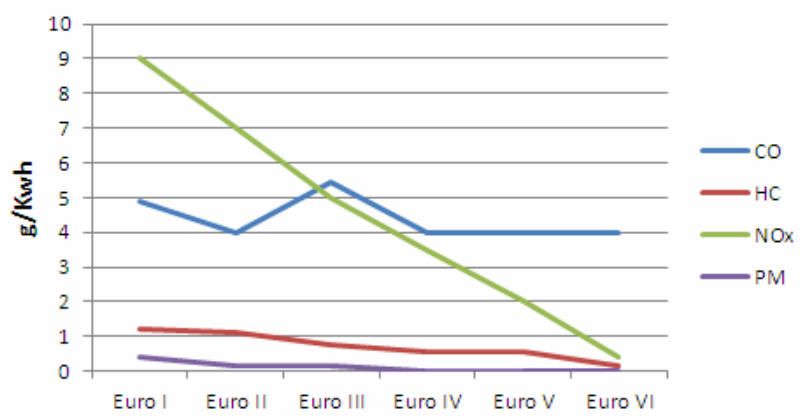

Figure 7. Evolution of emission standards for heavy duty vehicles (HDV). Source: Own, based in directives 88/77/EC, 1999/96/EC, 2005/55/EC, 2005/78/EC and 2007/46/EC.

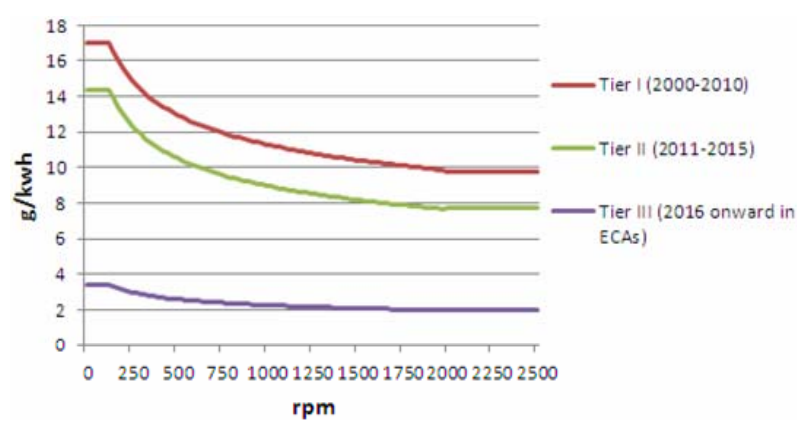

Figure 8. Emission standards set by the $\mathrm{NO}_{\mathrm{x}}$ Technical Codes. Source: Own.

feasibility review; and reducing the sulphur content in fuels used in $\mathrm{SO}_{\mathrm{x}}$ ECAs to $1 \%$ by July 2010 and to $0.1 \%$ by January 2015. Moreover same amendments also introduced new $\mathrm{NO}_{\mathrm{x}}$ emission limits for the so called Tier III engines, applicable to ships constructed after January 2016 and operating in $\mathrm{NO}_{\mathrm{x}}$ ECAs. Finally the revised Annex will also allow to designate ECAs for $\mathrm{SO}_{\mathrm{x}}, \mathrm{PM}$ and $\mathrm{NO}_{\mathrm{x}}$.

The regulatory framework established by the MARPOL Annex VI was transposed into EU law by Directive 2005/33/EC [24] in July 2005. This directive known as 
the "Sulphur Directive" does not only transpose what Annex VI establishes, but complements it introducing more stringent limits for passenger ships (1.5\% sulphur content limit in the fuel) and ships at port ( $0.1 \%$ sulphur content limit in the fuel), Figure 9.

\subsubsection{Baseline and Prospective Scenarios}

After a thorough review of the regulatory framework for road and maritime transport, the scenarios in Tables 2 and 3 were created for the environmental performance assessment. These scenarios extend from 2012 (baseline year) until 2020 and include also specific scenarios representing ship types (passenger ships) and areas $\left(\mathrm{SO}_{\mathrm{x}}\right.$ or/and $\mathrm{NO}_{\mathrm{x}}$ ECAs) in which due to their higher sensitiveness more stringent regulations are applied.

On the other hand for road transport only four scenarios were built. These correspond to each of the four years considered in the marine scenarios (2012, 2015, 2016 and 2020), as the emissions regulatory framework is common to the EU27 and to the European truck fleet. Hence for emissions calculation purposes, only the engine technology in place within the fleet needs to be estimated.

\section{Case Study}

In this section the intra-European trade link between Madrid and Dortmund is chosen to show the potential of the developed simulation model. This trade link is of particular interest as one of the few services regarded as Motorways of the Sea in Europe runs between Bilbao and Zeebrugge. Table 4 shows the input data that needs to be entered by the model user.

Once the data has been introduced, the model relates this input data with all the different combinations arising from the considered independent variables. The two sets of independent variables and values considered, shown in Tables 5 and 6, result in two different combinatorial matrices, formed by 7200 and 20,300 different combinations in the unimodal and multimodal options respectively.

Running the simulation model a result is obtained for each of the considered combinations, enabling the identification of the most efficient alternative for the considered trade link and making possible a sensitivity analysis

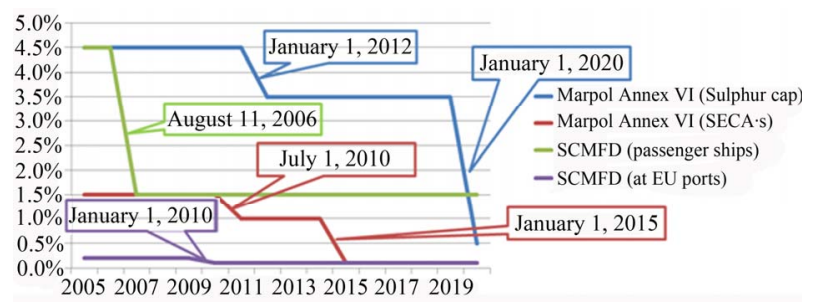

Figure 9. Evolution of the sulphur cap in marine fuels. Source: Own. of the considered variables (year, regulatory framework, load factor, Intermodal Transport Unit (ITU), etc.).

\section{Results Discussion}

The simulation model provides the user with thousands of results therefore the results data analysis process is of paramount importance to take maximum advantage of the developed model. In this section, results of typical case scenarios in the considered trade link are given as examples.

The following two figures, Figures 10 and 11, present external costs of both transport alternatives being assessed in $€ / \mathrm{tm} \cdot \mathrm{km}$. For this purpose some pre-defined conditions with regards to load factor, empty trip distance, average speeds, etc. have been assumed.

Looking Figure 12 is clear at glance that not always multimodal transport chains perform better than road transport with regards to air pollutants and GHGs external costs. Broadly speaking the considered combinations could be classified in the following order from the greenest to the most damaging: multimodal transport (road + large container ships); multimodal transport (road + small container ships); multimodal transport (road + ConRo ships); unimodal transport (road only); and finally multimodal transport (road + RoRo).

Thus multimodal transport chains using RoRo ships, regardless their engine type and in this particular trade link, perform worse than road transport. Considering a $60 \%$ ITU load factor and a fully loaded RoRo ship the external costs of a multimodal transport chain due to

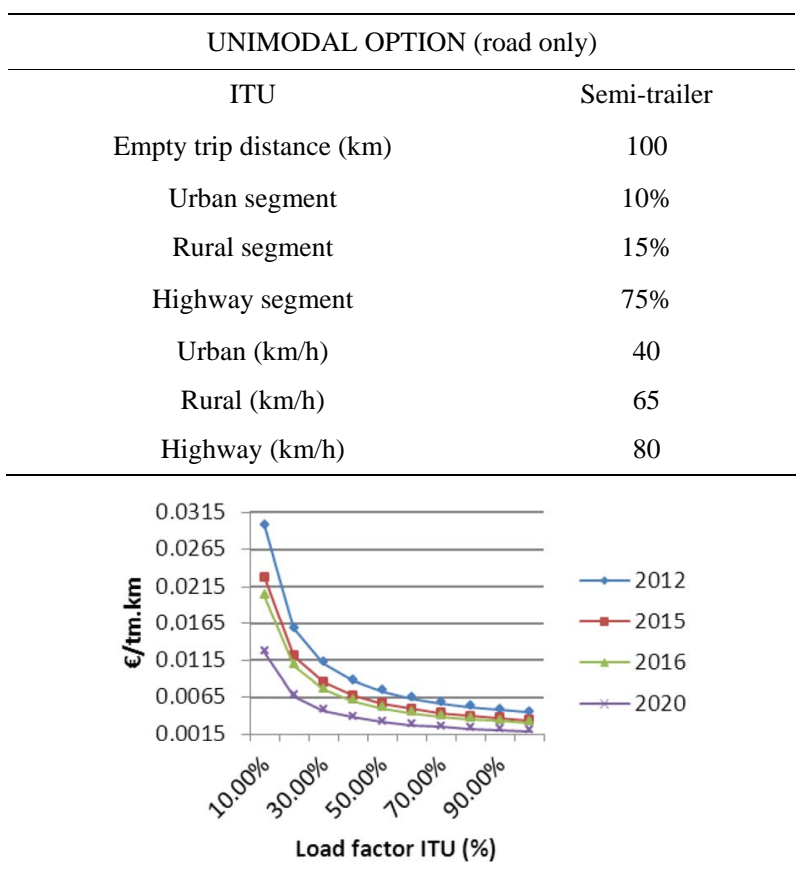

Figure 10. Typical road transport case scenario. Source: Own. 
Table 2. Marine scenarios and emissions legislation. Source: Own.

\begin{tabular}{|c|c|c|c|c|}
\hline Scenario & Year & Regulatory framework & $\begin{array}{l}\text { Sulphur } \\
\text { content } \\
\text { In the fuel }\end{array}$ & $\mathrm{NO}_{\mathrm{x}}$ emission standard \\
\hline 2012 baseline & 2012 & MARPOL (Annex VI-Global sulphur cap) & $3.50 \%$ & Tier 0 (52\%)/Tier I (44\%)/Tier II (4\%) \\
\hline 2012 ROPAX & 2012 & Dir. Sulphur Content of Marine Fuels (DSCMF)-passenger ships & $1.50 \%$ & Tier 0 (52\%)/Tier I (44\%)/Tier II (4\%) \\
\hline 2012 SECA & 2012 & $\mathrm{SO}_{\mathrm{x}} \mathrm{ECA}$ & $1 \%$ & Tier 0 (52\%)/Tier I (44\%)/Tier II (4\%) \\
\hline 2015 baseline & 2015 & MARPOL (Annex VI-Global sulphur cap) & $3.50 \%$ & Tier 0 (40\%)/Tier I (44\%)/Tier II (16\%) \\
\hline 2015 ROPAX & 2015 & DSCMF-passenger ships & $1.50 \%$ & Tier 0 (40\%)/Tier I (44\%)/Tier II (16\%) \\
\hline 2015 SECA & 2015 & $\mathrm{SO}_{\mathrm{x}} \mathrm{ECA}$ & $0.10 \%$ & Tier 0 (40\%)/Tier I (44\%)/Tier II (16\%) \\
\hline 2016 baseline & 2016 & MARPOL (Annex VI-Global sulphur cap) & $3.50 \%$ & Tier 0 (36\%)/Tier I (44\%)/Tier II (20\%) \\
\hline 2016 ROPAX & 2016 & DSCMF-passenger ships & $1.50 \%$ & Tier 0 (36\%)/Tier I (44\%)/Tier II (20\%) \\
\hline 2016 SECA & 2016 & $\mathrm{SO}_{\mathrm{x}} \mathrm{ECA}$ & $0.10 \%$ & Tier 0 (36\%)/Tier I (44\%)/Tier II (20\%) \\
\hline 2016 NECA & 2016 & $\mathrm{NO}_{\mathrm{x}} \mathrm{ECA}$ & $3.50 \%$ & Tier 0/I/II (0\%)/Tier III (100\%) \\
\hline 2016 SECA/NECA & 2016 & $\mathrm{SO}_{\mathrm{x}}$ and $\mathrm{NO}_{\mathrm{x}} \mathrm{ECA}$ & $0.10 \%$ & Tier 0/I/II (0\%)/Tier III (100\%) \\
\hline 2016 ROPAX/NECA & 2016 & DSCMF-passenger ships and $\mathrm{NO}_{\mathrm{x}} \mathrm{ECA}$ & $1.50 \%$ & Tier 0/I/II (0\%)/Tier III (100\%) \\
\hline 2020 baseline & 2020 & MARPOL (Annex VI-Global sulphur cap) & $0.50 \%$ & Tier 0 (20\%)/Tier I (44\%)/Tier II (36\%) \\
\hline 2020 SECA & 2020 & $\mathrm{SO}_{\mathrm{x}} \mathrm{ECA}$ & $0.10 \%$ & Tier 0 (20\%)/Tier I (44\%)/Tier II (36\%) \\
\hline 2020 NECA & 2020 & $\mathrm{NO}_{\mathrm{x}} \mathrm{ECA}$ & $0.50 \%$ & Tier 0/I/II (0\%)/Tier III (100\%) \\
\hline 2020 SECA/NECA & 2020 & $\mathrm{SO}_{\mathrm{x}}$ and $\mathrm{NO}_{\mathrm{x}} \mathrm{ECA}$ & $0.10 \%$ & Tier 0/I/II (0\%)/Tier III (100\%) \\
\hline
\end{tabular}

Table 3. Road transport scenarios and engine technology. Source: Own.

\begin{tabular}{cc}
\hline Scenario & Engine technology in the fleet \\
\hline \multirow{2}{*}{2012} & Euro II (6.8\%) Euro III (45.5\%) \\
& Euro IV (27.3\%) Euro V (20.5\%) \\
2015 & Euro III (25\%) Euro IV (27.3\%) \\
& Euro V (29.5\%) Euro VI (18,2\%) \\
2016 & Euro III (15.9\%) Euro IV (27.3\%) \\
2020 & Euro V (29.5\%) Euro VI (27.3\%) \\
& Euro IV (6.8\%) Euro V (29.5\%) Euro VI (63.6\%) \\
\hline
\end{tabular}

emissions to air are quantified in $0.0083 € / \mathrm{tm} . \mathrm{km}$, whereas the external costs of road transport in this trade link are quantified in $0.0063 € / \mathrm{tm} . \mathrm{km}$. There are, however, other case scenarios in which depending on the ship type, ship's load factor and route characteristics the multimodal option is the preferred one.

\section{Conclusions and Further Recommendations}

Such a model is definitely a significant contribution for the understanding of the considered transport chains environmental performances, and can be easily embedded into an optimization model in order to find the best solution for the given conditions and circumstances. In this respect it allows the implementation of optimized green logistic strategies and enables the design of more efficient policy measures not only because of the understanding of driving factors, but because their outcome is

\begin{tabular}{|c|c|}
\hline \multicolumn{2}{|c|}{ MULTIMODAL OPTION (road + SSS) } \\
\hline Year & 2012 \\
\hline Empty trip distance $(\mathrm{km})$ & 100 \\
\hline Regulatory framework & Global sulphur cap \\
\hline Load factor (ITU) & $60.00 \%$ \\
\hline Urban segment & $10 \%$ \\
\hline Rural segment & $15 \%$ \\
\hline Highway segment & $75 \%$ \\
\hline Urban $(\mathrm{km} / \mathrm{h})$ & 40 \\
\hline Rural $(\mathrm{km} / \mathrm{h})$ & 65 \\
\hline Highway $(\mathrm{km} / \mathrm{h})$ & 80 \\
\hline
\end{tabular}

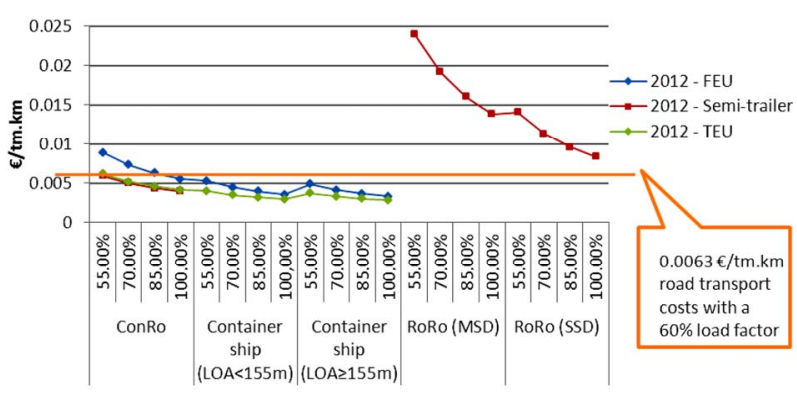

Figure 11. Typical multimodal transport case scenario. Source: Own.

predicted more accurately. In other words, the developed model allows to carry out cost benefit analyses of either environmental policies or emission abatement technologies. Thus, the model enables to rank each of the consid- 
Table 4. Model input data for loaded leg.

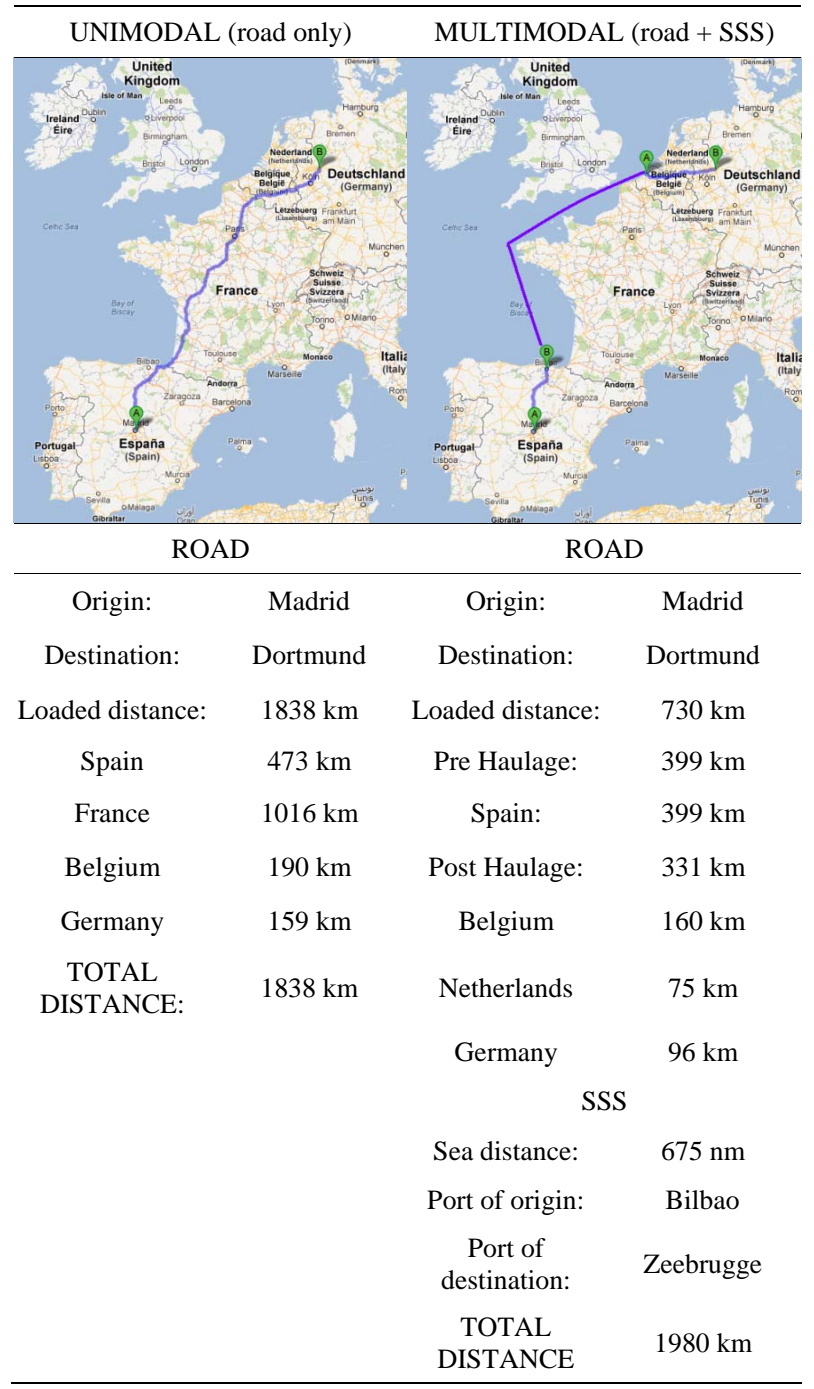

Table 5. Independent variables and considered values in the unimodal model. Source: Own.

\begin{tabular}{|c|c|c|c|c|}
\hline Year & $\begin{array}{l}\text { Load } \\
\text { Factor } \\
\text { (ITU) }\end{array}$ & $\begin{array}{l}\text { Segments } \\
\text { (urban/rural } \\
\text { (highway) }\end{array}$ & $\begin{array}{c}\text { Average } \\
\text { speeds in km/h } \\
\text { (urban/ rural } \\
\text { (highway) }\end{array}$ & $\begin{array}{c}\text { Empty trip } \\
\text { distance } \\
(\mathrm{km})\end{array}$ \\
\hline 2012 Semi-trailer & $10 \%$ & $10 \%-75 \%-15 \%$ & $30-55-70$ & 0 \\
\hline $2015 \begin{array}{c}\text { CarCarrier } \\
\text { trailer }\end{array}$ & $20 \%$ & $10 \%-60 \%-30 \%$ & $40-65-80$ & 100 \\
\hline 2016 & $30 \%$ & $10 \%-45 \%-45 \%$ & $50-70-85$ & 200 \\
\hline \multirow[t]{7}{*}{2020} & $40 \%$ & $10 \%-30 \%-60 \%$ & & 300 \\
\hline & $50 \%$ & $10 \%-15 \%-75 \%$ & & 400 \\
\hline & $60 \%$ & & & 500 \\
\hline & $70 \%$ & & & \\
\hline & $80 \%$ & & & \\
\hline & $90 \%$ & & & \\
\hline & $100 \%$ & & & \\
\hline
\end{tabular}

Table 6. Independent variables and considered values in the multimodal model. Source: Own.

\begin{tabular}{|c|c|c|c|c|c|c|}
\hline Year & $\begin{array}{l}\text { Regulatory } \\
\text { framework }\end{array}$ & Ship type & $\begin{array}{l}\text { Load } \\
\text { Factor } \\
\text { (SHIP) }\end{array}$ & ITU & $\begin{array}{l}\text { Load } \\
\text { Factor } \\
\text { (ITU) }\end{array}$ & $\begin{array}{c}\text { Empty } \\
\text { trip } \\
\text { distance } \\
(\mathrm{km})\end{array}$ \\
\hline 2012 & G. sulphur cap & $\begin{array}{l}\text { Container } \\
\text { (LOA } \\
<155 \mathrm{~m} \text { ) }\end{array}$ & $55 \%$ & Semi-trailer & $40 \%$ & 0 \\
\hline 2015 & ROPAX & $\begin{array}{l}\text { Container } \\
\text { (LOA } \\
=155 \mathrm{~m})\end{array}$ & $70 \%$ & CarCarrier & $50 \%$ & 100 \\
\hline 2016 & SECA & $\begin{array}{l}\text { CarCarrier } \\
\text { (LOA } \\
<155 \text { m) }\end{array}$ & $85 \%$ & TEU & $60 \%$ & 200 \\
\hline 2020 & NECA & $\begin{array}{c}\text { CarCarrier } \\
\text { (LOA } \\
=155 \mathrm{~m})\end{array}$ & $100 \%$ & FEU & $70 \%$ & 300 \\
\hline & ROPAX-NECA & $\begin{array}{l}\text { RoRo } \\
\text { (MSD) }\end{array}$ & & & $80 \%$ & 400 \\
\hline & SECA-NECA & $\begin{array}{l}\text { RoRo } \\
\text { (SSD) }\end{array}$ & & & $90 \%$ & \\
\hline & & RoPax & & & $100 \%$ & \\
\hline & & ConRo & & & & \\
\hline
\end{tabular}

ered transport alternatives according to different criteria in each case scenario: Environmental performance per transport work $(€ / \mathrm{tkm})$ and Environmental performance per route $(€)$.

This distinction is relevant as factors such as detouring can turn the most environmentally friendly option per transport work unit (tkm), not the preferred one in a certain route. Covered distances are not usually equal in road and combined transport chains, being sometimes the decisive factor when it comes to most environmentally friendly alternative selection.

Results given for the analyzed trade link, in which does not exist a significant detouring difference between transport alternatives, make clear the differences in the environmental performance of the different combinations considered. Besides, some of the common maritime alternatives nowadays, regarding ship types, show worse performance figures which makes necessary to reconsider current practices. RoRo and RoPax ships weak performance is related to inherent characteristics such as smaller cargo capacity, higher engine power to ship size ratio and higher service speed; resulting these characteristics in higher consumption and hence higher emission factors per ton of cargo. However in favors of maritime transport and multimodal services needs to be said that this services usually achieve high ship load factors thus improving efficiencies overall the transport chain. Moreover there are other types of external costs such as noise, accidents and congestion which are negligible for maritime transport and on the contrary significant for road transport. On the other hand, looking into 2020 results 


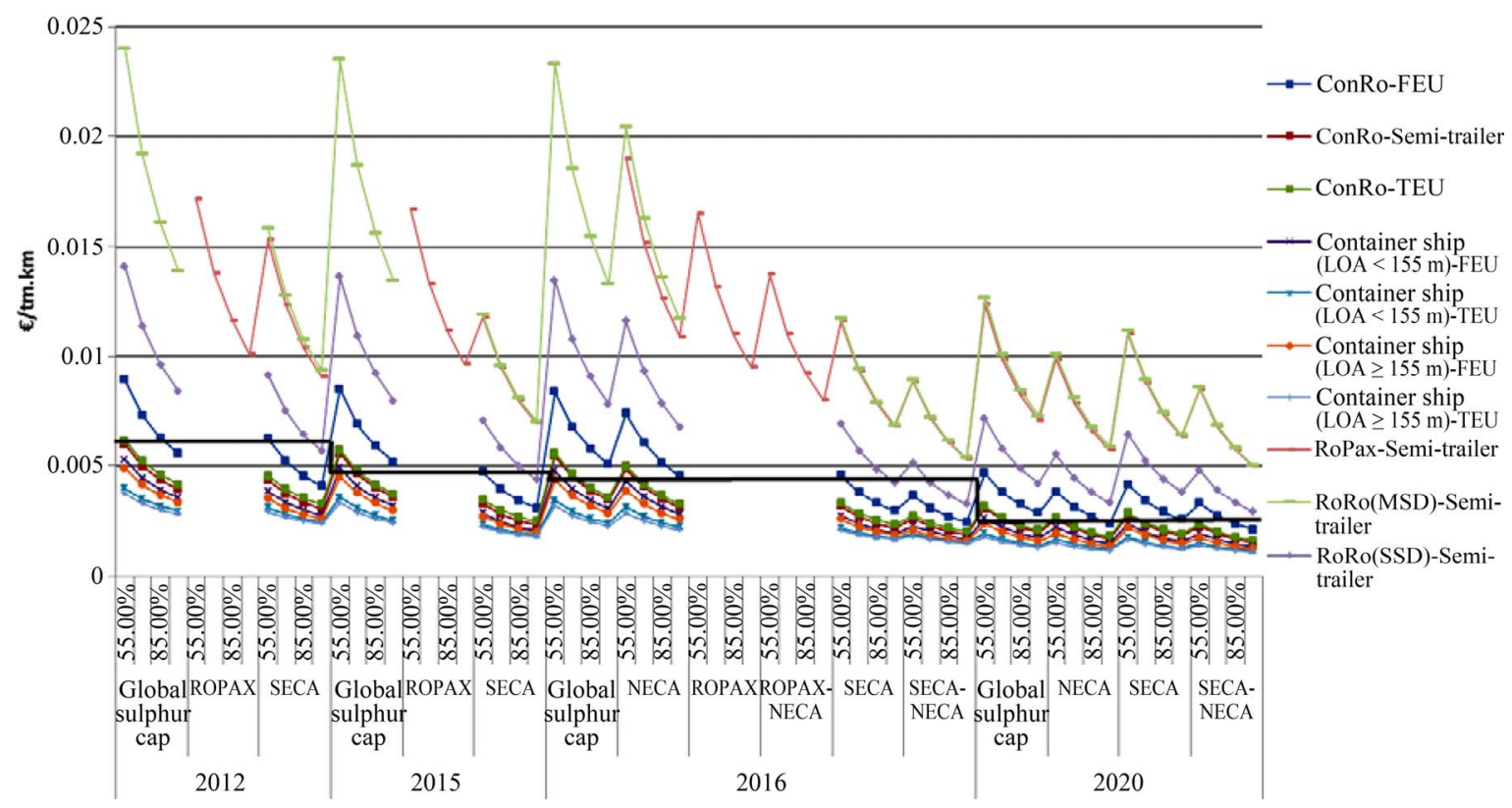

Figure 12. Typical multimodal transport case scenario (Madrid-Dortmund). Source: Own.

and comparing them with those obtained for 2012, the greening process of road transport takes place faster than that of maritime transport. This is due to a shorter fleet recycling period of road transport, 11 years on average against 25 years for maritime transport, which enables the faster introduction of new and greener technologies into the fleet. Although presented results focus in the comparison of SSS and road transport chains in a particular trade link, and hence some assumptions have been done regarding voyage data; the algorithm behind the model enables to carry out a sensitivity analysis of both transport chains with regards to the considered independent variables. In fact these is one of the areas for further research, as it enables the identification of dominant variables and hence contributes further tackling external costs. Moreover it would also be interesting the introduction into the model of other external costs such as noise, accidents and congestion that unlike emissions to air will definitely favor combined transport using SSS. Finally, in the same way that the introduction of other external costs would contribute to the comprehensiveness of the model, considering indirect emissions occurring upstream and downstream the transport chain would provide the model with more comparable and precise results.

\section{REFERENCES}

[1] European Commission, "Roadmap to a Single European Transport Area-Towards a Competitive and Resource Efficient Transport System," White Paper, COM, Brussels, 2011.

[2] Eurostat, 2012. http://epp.eurostat.ec.europa.eu
[3] A. Marques, J. Fuinhas and B. Gonçalves, "Dieselization and Road Transport $\mathrm{CO}_{2}$ Emissions: Evidence from Europe,” Low Carbon Economy, Vol. 3 No. 3, 2012, pp. 54-62. doi:10.4236/lce.2012.33008

[4] International Maritime Organization (IMO), "Second IMO GHG Study 2009,” 2009.

[5] M. Vivanco, I. Palomino, J. Garrido, M. González, G. Alonso and F. Martín, "Impact of the Transboundary Transport of Air Pollutants on Air Quality in Spain," Journal of Environmental Protection, Vol. 3 No. 9A, 2012, pp. 1167-1175. doi:10.4236/jep.2012.329135

[6] M. Castells, J. J. Usabiaga and F. X. Martínez de Osés, "Manoeuvring and Hoteling External Costs: Enough for Alternative Energy Sources?” Maritime Policy \& Management, 2013. doi:10.1080/03088839.2013.782441

[7] A. M. Fet, O. Michelsen and T. Johnsen "Environmental Performance of Transportation, a Comparative Study," NTNU, Trondheim, 2000.

[8] H. Essen, O. Bello, J. Dings and R. Van den Brink, "To Shift or Not to Shift, That's the Question,” CE, Delft, 2003.

[9] E. Boer, F. Brouwer, H. Essen and STREAM, "Studie naar Transport Emissies van Alle Modaliteiten," CE, Delft, 2008.

[10] E. Delhaye, T. Breemersch, K. Vanherle, J. Kehoe, M. Liddane and K. Riordan "The Competitiveness of European Short-Sea Freight Shipping Compared with Road and Rail Transport,” Final Report, 2010.

[11] E. Boer, M. Otten and H. Essen, "Comparison of Various Transport Modes on a EU Scale with the STREAM Database,” CE, Delft, 2011.

[12] S. Papadimitriou, E. Tzannatos and I. Koliousis, "Energy Efficiency Assessment of Passenger Shipping in Greece," Maritime Transport V Conference. Technological, Inno- 
vation and Research, Barcelona, 2012.

[13] H. M. Hjelle and E. Fridell "When is Short Sea Shipping Environmentally Competitive?” Environmental HealthEmerging Issues and Practice, Chapter 1, 2012,.

[14] C. Trozzi, et al., "EMEP/EEA Air Pollutant Emission Inventory Guidebook 2009,” Technical Report, No. 9, Part B, chapter 1.A.3.b, European Environment Agency, 2009.

[15] A. Miola, B. Ciuffo, E. Giovine and M. Marra, "Regulating Air Emissions from Ships the State of Art on Methodologies, Technologies and Policy Options," JRC Reference Reports, European Union, 2010.

[16] M. Holland and P. Watkiss "Benefits Table Database: Estimates of the Marginal External Costs of Air Pollution in Europe (BETA),” AEA Technology, NETCEN, 2002.

[17] M. Holland, et al., "The Clean Air for Europe (CAFE) Programme: Towards a Thematic Strategy for Air Quality,” AEA Technology, 2005.

[18] C. Whall, et al., "UK Ship Emissions Inventory,” Final Report, Entec, 2010.
[19] L. Ntziachristos, et al., "EMEP/EEA Air Pollutant Emission Inventory Guidebook 2009,” Technical Report, No. 9, Part B, chapter 1.A.3.d, European Environment Agency, 2009.

[20] J. Moldanova, et al., "Emission Factors for ShippingFinal Data for Use in Transphorm Emission Inventories,” Transphorm Deliverable D1.2.3, Type R, 2012.

[21] European Commission, "Directive 2009/30/EC of the European Parliament and of the Council," Official Journal of the European Union, 2009.

[22] European Commission, "Directive 1998/70/EC of the European Parliament and of the Council," Official Journal of the European Union, 1998.

[23] International Maritime Organization (IMO), "Revised MARPOL Annex VI-Regulations for the Prevention of Air Pollution from Ships and $\mathrm{NO}_{\mathrm{x}}$ Technical Code,” London, 2009.

[24] European Commission, "Directive 2005/33/EC of the European Parliament and of the Council," Official Journal of the European Union, 2005. 